\title{
Phytochemical and HPTLC Studies on Fruit Extracts of Momordica cymbalaria Fenzl, a Medicinally Important Plant
}

\section{Shantakani SRINIVASULU*, Yarrama PALLAVI, Bollu GAYATRI DEVI, Hemalatha K. PADMA JYOTHI}

\author{
Andhra University, Department of Biochemistry,Visakhapatnam, India; srinivashcu06@gmail.com ("corresponding author); \\ yarrama.pallavi89@gmail.com;gayatribollu@gmail.com; hemalathakpj@gmail.com
}

\begin{abstract}
Preliminary screening of phytochemicals is a valuable step in the detection of bioactive principles present in medicinal plants, which subsequently may lead to drug discovery and development. In the present study, chief phyto-constituents of the Momordica cymbalaria were identified. Preliminary screening of phytochemicals was done by using three extraction methods: maceration, soxhlation and reflux with hexane, ethyl acetate and methanol. All the nine extracts showed the presence of flavonoids, phenols, steroids and terpenoids that were obtained by the three extraction methods. The present work also attempted to optimize the HPTLC fingerprint profiles of secondary metabolites in hexane, ethyl acetate and methanolic fruit extracts of $M$. cymabalaria. Soxhlated methanolic fruit extract was rich in secondary compounds and exhibited more biological activity than the other extracts. Hence future study is needed to isolate potential bioactive principle from fruit extract of $M$. cymbalaria.
\end{abstract}

Keywords: chromatography, HPTLC, maceration, Momordica cymbalaria, phytochemicals, reflux, soxhlation

\section{Introduction}

Plants are excellent sources of medicine. Various parts of plants such as fruit, leaves, stem, bark and roots are used for therapeutic purposes (Bruneton, 1993). Medicinal plants play a crucial role for the treatment of various disease conditions, such as diabetes and malaria (Fola, 1993). The availability and relatively cheaper cost of medicinal plants, make them more attractive as therapeutic agents when compared to 'modern' medicines (Agbor and Ngogang, 2005; Agbor et al., 2005a).

The medicinal value of plants is due to the presence of some chemical substances known as phytochemicals that produce a definite physiological action on the human body. Knowledge of the chemical constituents of the plant is essential, not only for the discovery of therapeutic agents, but also such information may be of value as precursors for the synthesis of complex chemical substances (Ilango et al., 2012). Medicinal plants are used as herbal preparations produced by subjecting plant materials to various extraction procedures such as extraction, fractionation, purification, concentration or other physical or biological processes which may be produced for immediate consumption or as a basis for herbal products (Sofowora et al., 1996).
Momordica cymbalaria is one such medicinal plant that belongs to the family Cucurbitaceae, originating in tropical regions of India and South East Asia. M. cymbalaria Fenzl. is commonly known as Karchikai (Kannada), Athalakkai (Tamil) or Kasarakayee (Andra Pradesh) and Kakrol (India). It has been used in various Asian traditional medicine systems for a long time. The plant is traditionally used for the treatment of diabetes mellitus, rheumatism, ulcer, skin disease and diarrhoea. The fruit of this plant (Fig. 1) possess hypoglycaemic, hypolipidemic, cardioprotective, hepatoprotective, nephroprotective and antioxidant properties. Owing to anthropogenic activities, such as habitat destruction, grazing, urbanization, poor seed viability and germination of $M$. cymbalaria, the species is under threat of extinction (Jeyadevi et al., 2012).

High performance thin layer chromatography (HPTLC) is becoming a routine analytical technique because of the advantages that include the small amount of mobile phase required, the speed of the method and the possibility of analysing several samples simultaneously (i.e. on the same plate), unlike HPLC. It thus reduces analysis time and cost per analysis. Cloudy samples and suspensions can also be analyzed directly by HPTLC. Automatic sample application is possible and repeated scanning can be performed on the same plate, so scanning conditions can be changed. 

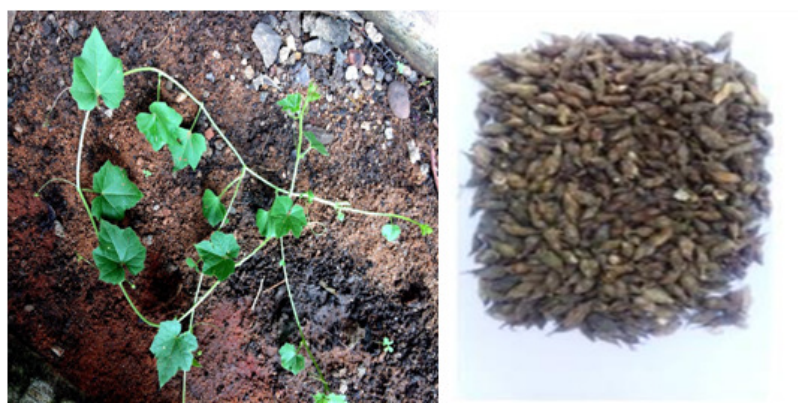

Fig. 1. Momordica cymbalaria fruits

The present study is an attempt to optimize the simultaneous HPTLC fingerprint profiles of secondary metabolites in hexane, ethyl acetate, and methanol fruit extracts of M. cymabalaria.

\section{Materials and Methods}

\section{Collection of plantmaterial}

The plant material, unripened fruits of M. cymbalaria, was collected from the Eastern Ghats, Kurnool district, Andhra Pradesh, during the month of November, 2013. Taxonomic identification of the plant was carried out with the herbarium present in the Department of Botany, Andhra University, Visakhapatnam. The plant fruit material was shade dried, powdered and stored in desiccators till further use. These powders were subjected to maceration, soxhlet extraction and reflux solvent extraction process with hexane, ethyl acetate and methanol separately to check the presence of thermolabile and thermostable components in M. cymbalaria as they may be lost at elevated temperature.

\section{Preparation of test solutions}

The preliminary tests for the detection of secondary metabolites were carried out with hexane, ethyl acetate and methanolic extracts. Five grams of powder was dissolved in $100 \mathrm{ml}$ of the respective solvents and filtered through Whatmann No.1 filter paper. Thus, the filtrates obtained were used as test solutions for the following preliminary phytochemical screening tests.

\section{Phytochemical evaluation (Qualitative methods)}

Phytochemical tests were carried out for all the extracts as per the standard methods (Roopashree et al., 2008; Obasi et al., 2010).

\section{Test for carbohydrates}

To $2 \mathrm{ml}$ of plant extract, $1 \mathrm{ml}$ of Molisch's reagent and a few drops of concentrated sulfuric acid were added. Presence of purple or reddish colour indicated the presence of carbohydrates.

\section{Test for tannins}

To $1 \mathrm{ml}$ of plant extract, $2 \mathrm{ml}$ of $5 \%$ ferric chloride were added. Formation of dark blue or greenish black indicated the presence of tannins.

\section{Test for saponins}

To $2 \mathrm{ml}$ of plant extract, $2 \mathrm{ml}$ of distilled water were added and shaken in a graduated cylinder for 15 minutes lengthwise. Formation of a $1 \mathrm{~cm}$ layer of foam indicated the presence of saponins.

\section{Test for flavonoids}

To $2 \mathrm{ml}$ of plant extract, $1 \mathrm{ml}$ of $2 \mathrm{~N}$ sodium hydroxide was added. Presence of yellow colour indicated the presence of flavonoids.

\section{Test for alkaloids}

To $2 \mathrm{ml}$ of plant extract, $2 \mathrm{ml}$ of concentrated hydrochloric acid were added. Then a few drops of Mayer's reagent were added. The presence of green colour or white precipitate indicated the presence of alkaloids.

\section{Test for quinones}

To $1 \mathrm{ml}$ of extract, $1 \mathrm{ml}$ of concentrated sulfuric acid was added. Formation of red colour indicated the presence of quinones.

\section{Test for glycosides}

To $2 \mathrm{ml}$ of plant extract, $3 \mathrm{ml}$ of chloroform and $10 \%$ ammonia solution were added. Formation of pink colour indicated the presence of glycosides.

\section{Test for cardiac glycosides}

To $0.5 \mathrm{ml}$ of extract, $2 \mathrm{ml}$ of glacial acetic acid and a few drops of $5 \%$ ferric chloride were added. This was under layered with $1 \mathrm{ml}$ of concentrated sulfuric acid. The formation of brown ring at the interface indicated the presence of cardiac glycosides.

\section{Test for terpenoids}

To $0.5 \mathrm{ml}$ of extract, $2 \mathrm{ml}$ of chloroform was added and concentrated sulfuric acid was added carefully. Formation of red brown color at the interface indicated the presence of terpenoids.

\section{Test for triterpenoids}

To $1.5 \mathrm{ml}$ of extract, $1 \mathrm{ml}$ of Liebermann-Burchard Reagent (acetic anhydride + concentrated sulfuric acid) was added. Formation of blue green colour indicated the presence of triterpenoids.

\section{Test for phenols}

To $1 \mathrm{ml}$ of the extract, $2 \mathrm{ml}$ of distilled water followed by a few drops of $10 \%$ ferric chloride were added. Formation of blue or green color indicated the presence of phenols.

\section{Test for coumarins}

To $1 \mathrm{ml}$ of extract, $1 \mathrm{ml}$ of $10 \% \mathrm{NaOH}$ was added. Formation of yellow colour indicated the presence of coumarins.

\section{Steroids and phytosteroids}

To $1 \mathrm{ml}$ of plant extract equal volume of chloroform was added and subjected with a few drops of concentrated sulfuric acid. Appearance of brown ring indicated the presence of steroids and appearance of the bluish brown ring indicated the presence of phytosteroids. 
352

\section{Phlobatannins}

To $1 \mathrm{ml}$ of plant extractm few drops of $2 \% \mathrm{HCl}$ were added. Appearance of red colour precipitate indicated the presence of phlobatannins.

\section{Anthraquinones}

To $1 \mathrm{ml}$ of plant extract, few drops of $10 \%$ ammonia solution were added, appearance pink colour precipitate indicated the presence of anthraquinones.

\section{Phytochemical evaluation (Quantitative methods) Analysis of total phenolics}

The total phenolics were determined using the Folin Ciocalteau reagent as reported by Javanmardi et al. (2003). To $50 \mu \mathrm{l}$ of the plant extract, $2.5 \mathrm{ml}$ of diluted Folin Ciocalteau reagent and $2 \mathrm{ml}$ of $7.5 \%(\mathrm{w} / \mathrm{v})$ sodium carbonate were added and incubated at $45^{\circ} \mathrm{C}$ for $15 \mathrm{~min}$. The absorbance values of all samples were measured in a spectrophotometer (Shimazdu UV 1800) at $765 \mathrm{~nm}$. The concentration of total phenolic content in plant extracts was calculated from the calibration curve of Gallic acid and it was expressed as Gallic acid equivalents/gram fresh weight (Ishtiaq et al., 2014). Each experiment had three replicates.

\section{Determination of total flavonoids}

Total flavonoid content was measured by aluminum chloride colorimetric assay as described by Marinova et al. (2005). One $\mathrm{ml}$ of plant extract was added to $10 \mathrm{ml}$ volumetric flask containing $4 \mathrm{ml}$ of distilled water. To the above mixture, $0.3 \mathrm{ml}$ of $5 \% \mathrm{NaNO} 2$ were added. After 5 minutes, $0.3 \mathrm{ml}$ of $10 \% \mathrm{AlCl} 3$ was added. At $6^{\text {th }} \mathrm{min}, 2 \mathrm{ml}$ of $1 \mathrm{M} \mathrm{NaOH}$ was added and the volume was made up to $10 \mathrm{ml}$ with distilled water. The solution was mixed well and the absorbance was measured against prepared reagent blank at $510 \mathrm{~nm}$. The total flavonoid content in plant extracts was calculated from the calibration curve of catechin and it was expressed as Gallic acid equivalents/gram fresh weight (Merculieff et al., 2014). Each experiment had three replicates.

\section{Total steroids}

Total steroid content of the extract was determined according to the standard procedure (Trease and Evans, 1996). To $1 \mathrm{ml}$ of plant extract, $2 \mathrm{ml}$ of $4 \mathrm{~N}$ Sulphuric acid, $2 \mathrm{ml}$ of $0.5 \%$ Ferric chloride, $0.5 \mathrm{ml}$ of $0.5 \%$ potassium hexacyanoferrate were added and kept in water bath at 70$90{ }^{\circ} \mathrm{C}$ for $30 \mathrm{~min}$. After removal, it was diluted with distilled water up to $5 \mathrm{ml}$, the absorbance was measured at $780 \mathrm{~nm}$ against blank. Sitosterol was used as a standard.

\section{HPTLC analysis of $M$. cymbalaria fruit extract}

One hundred $\mathrm{mg}$ powder were dissolved in $5 \mathrm{ml}$ of the respective solvents and the solution was centrifuged at 3,000 rpm for $5 \mathrm{~min}$ and used for HPTLC analysis as test solution. The samples $(2 \mu \mathrm{l})$ were spotted in the form of band width $5 \mathrm{~mm}$ with a Camag microlitre syringe on precoated silica gel glass plate $60 \mathrm{~F}-254(10 \mathrm{~cm} \times 10 \mathrm{~cm})$ with $250 \mu \mathrm{m}$ thickness (E-Merck, Darmstadt, Germany) using a Camag Linomat IV (Switzerland). The plates were prewashed with methanol and activated at $60{ }^{\circ} \mathrm{C}$ for $5 \mathrm{~min}$ prior to chromatography. The sample loaded plate was kept in thin-layer chromatography (TLC) twin through developing chamber after saturated with solvent vapor with respective mobile phase and the plate was developed in the respective mobile phase up to $90 \mathrm{~mm}$. The toulene:acetone:water $(20: 40: 1)$ was employed as mobile phase for secondary metabolites. Linear ascending development was carried out in $(10 \mathrm{~cm} \times 10 \mathrm{~cm})$ twin trough glass chamber (Camag, Mutenz, Switzerland) saturated with the mobile phase and the chromatoplate was developed twice with the same mobile phase to get good resolution of phytochemical contents. The optimized chamber saturation time for mobile phase was $30 \mathrm{~min}$ at room temperature $25 \pm 2{ }^{\circ} \mathrm{C}$. The developed plate was dried by hot air to evaporate solvents from the plate. The plate was kept in photo-documentation chamber (CAMAG REPROSTAR 3) and captured the images under UV light at 254 and $366 \mathrm{~nm}$. The plate was photo-documented at UV $366 \mathrm{~nm}$ and daylight using photodocumentation (CAMAG REPROSTAR 3) chamber. Finally, the plate was fixed in scanner stage and scanning was done at 254 and $366 \mathrm{~nm}$. Densitometric scanning was performed on Camag TLC scanner III and operated by CATS software (V 3.15, Camag) (Yamunadevi et al., 2011).

\section{Results}

\section{Phytochemical constituents}

The phytochemical tests showed the presence of major secondary metabolites such as saponins, flavonoids, terpenes, quinones, steroids and alkaloids (Table 1). These tests were based on the visual observation of colour modification or precipitate formation after the addition of specific reagents.

Preliminary screening of phytochemicals was done by using three extraction methods maceration, soxhlation and reflux. Extracts were prepared with hexane, ethyl acetate and methanol respectively, thus obtaining nine extracts, which all showed positive results for flavonoids, phenolics, steroids and terpenoids. Presence of alkaloids was seen in hexane extracts of both maceration and soxhalation and in methanol extract of reflux. Quinones were present in hexane and ethyl acetate of maceration, hexane extract of soxhalation and hexane and methanol extracts of reflux. Saponins gave positive results in different extracts like hexane and methanol of maceration, hexane of soxhalation and hexane extract of reflux.

The results of quantitative analysis of phytochemicals were shown in Table 1. The total phenolic content was more in soxhlated methanolic extract, total flavonoids were more in methanol extracts of both maceration and soxhalation. More steroid content were observed in hexane and methanol extracts of soxhalation.

\section{Phytochemical analysis of maceration extract}

Maximum phenolic content was observed in the methanol extract $(74.65 \pm 0.04 \mathrm{GAE} \mathrm{mg} / \mathrm{g})$ followed by ethyl acetate $(62.16 \pm 0.07$ GAE $\mathrm{mg} / \mathrm{gm})$ and hexane $(58.65 \pm 0.19 \mathrm{GAE} \mathrm{mg} / \mathrm{gm})$ at $100 \mathrm{mg} / \mathrm{ml}$ concentration (Fig. 1). Total flavonoid content was maximum in the macerated methanolic extract $(79.64 \pm 0.13 \mathrm{GAE} \mathrm{mg} / \mathrm{gm})$, followed by ethyl acetate $(63.82 \pm 0.05 \mathrm{QE} \mathrm{mg} / \mathrm{gm})$ and hexane $(61.85 \pm 0.02 \mathrm{GAE} \mathrm{mg} / \mathrm{gm})$ at a concentration of 
Table 1. Preliminary phytochemical screening of fruit extracts of $M$. cymbalaria with different solvents (methanol, ethyl acetate and hexane) obtained by maceration, soxhalation and reflux methods

\begin{tabular}{|c|c|c|c|c|c|c|c|c|c|c|}
\hline $\begin{array}{l}\text { Extraction } \\
\text { method }\end{array}$ & Solvents & Alk & Fla & Gly & Phe & Qui & Sap & Ste & Tan & Terp \\
\hline \multirow[t]{3}{*}{ Maceration } & Hexane & ++ & ++ & - & + & ++ & + & + & - & + \\
\hline & $\begin{array}{l}\text { Ethyl } \\
\text { acetate }\end{array}$ & + & + & - & + & + & - & + & - & + \\
\hline & Methanol & - & + & - & + & - & + & + & - & + \\
\hline \multirow[t]{3}{*}{ Soxhalation } & Hexane & + & + & - & ++ & + & + & + & - & + \\
\hline & $\begin{array}{l}\text { Ethyl } \\
\text { acetate }\end{array}$ & - & - & - & - & - & - & + & - & + \\
\hline & Methanol & + & + & + & + & + & + & + & - & + \\
\hline \multirow[t]{3}{*}{ Reflux } & Hexane & - & - & - & + & + & + & + & - & + \\
\hline & $\begin{array}{l}\text { Ethyl } \\
\text { acetate }\end{array}$ & - & - & - & - & - & - & + & - & + \\
\hline & Methanol & + & + & - & + & + & - & + & - & + \\
\hline
\end{tabular}

Alk-Alkaloids, Fla-Flavonoids, Gly-Glycosides, Phe-Phenolics, Qui-Quinones, Sap-saponins, Ste-Steroids, Tan-Tannins, Terp-Terpenoids

$100 \mathrm{mg} / \mathrm{ml}$ (Fig. 2). Steroid content was maximum in the maceration methanolic extract $(79.98 \pm 0.22$ sito sterol equivalence $\mathrm{mg} / \mathrm{gm})$ followed by hexane $(76.74 \pm 0.25$ sito sterol equivalence $\mathrm{mg} / \mathrm{gm})$ and ethyl acetate extract $(56.83$ \pm 0.10 sito sterol equivalence $\mathrm{mg} / \mathrm{gm}$ ) at $100 \mathrm{mg} / \mathrm{ml}$ concentration (Fig. 3).

\section{Phytochemical analysis of soxhalation extract}

Total phenolic content was maximum in methanolic fruit extract $(79.65 \pm 0.04 \mathrm{GAE} \mathrm{mg} / \mathrm{gm})$ followed by ethyl acetate $(65.16 \pm 0.07 \mathrm{GAE} \mathrm{mg} / \mathrm{gm})$ and hexane $(52.11 \pm$

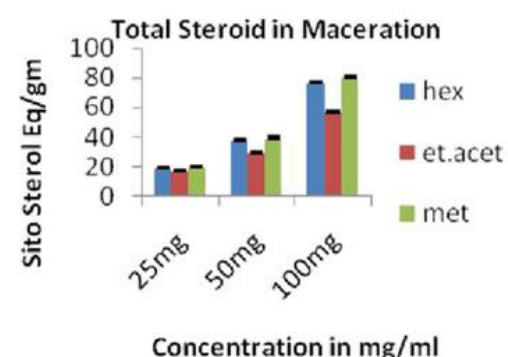

Fig. 1. Total steroid content in maceration

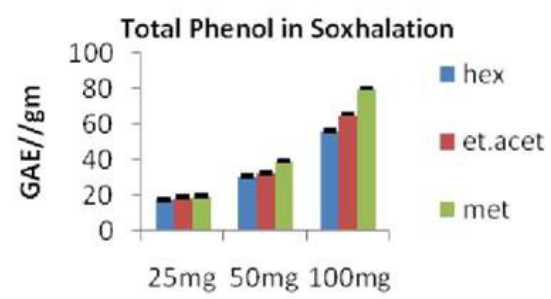

Concentration in $\mathrm{mg} / \mathrm{ml}$

Fig. 2. Total phenolic content in soxhalation
$0.19 \mathrm{GAE} \mathrm{mg} / \mathrm{gm}$ ) at $100 \mathrm{mg} / \mathrm{ml}$ concentration (Fig. 4). Total flavonoid content was maximum in the soxhalated methanolic extract $(80.2 \pm 0.40 \mathrm{GAE} \mathrm{mg} / \mathrm{gm})$ followed by ethyl acetate $(72.19 \pm 0.51 \mathrm{QE} \mathrm{mg} / \mathrm{gm})$ and hexane $(64.67$ $\pm 0.4 \mathrm{GAE} \mathrm{mg} / \mathrm{gm}$ ) at $100 \mathrm{mg} / \mathrm{ml}$ concentration (Fig. 5). Steroid content was maximum in the soxhalated methanolic extract $(84.73 \pm 0.01$ sito sterol equivalence $\mathrm{mg} / \mathrm{gm})$ followed by hexane $(83.51 \pm 0.07$ sito-sterol equivalence $\mathrm{mg} / \mathrm{gm})$ and ethyl acetate $(59.67 \pm 0.05$ sito sterol equivalence $\mathrm{mg} / \mathrm{gm}$ ) at $100 \mathrm{mg} / \mathrm{ml}$ concentration (Fig. 6).

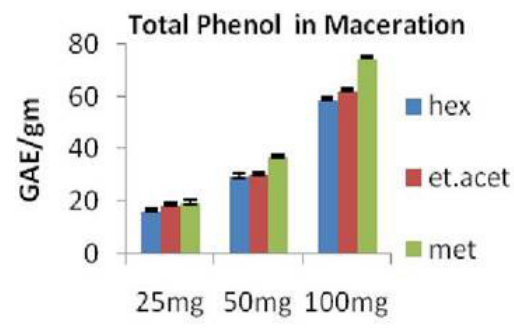

Concentration in $\mathrm{mg} / \mathrm{ml}$

Fig. 3. Total phenolic content in maceration

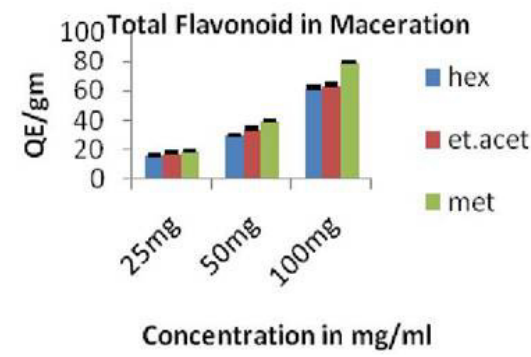

Fig. 4. Total flavonoid content in maceration 


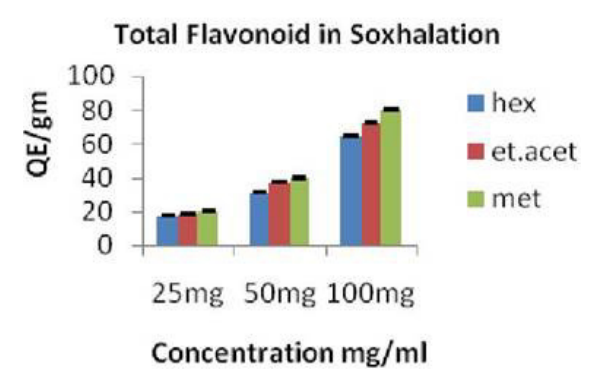

Fig. 5. Total flavonoid content in soxhlation

\section{Phytochemical analysis of reflux extract}

Total phenolic content was maximum in the methanolic extract prepared with reflux method $(77.40 \pm 0.42 \mathrm{GAE}$ $\mathrm{mg} / \mathrm{gm})$ followed by ethyl acetate (63.27 $\pm 0.07 \mathrm{GAE}$ $\mathrm{mg} / \mathrm{gm})$ and hexane $(59.52 \pm 0.18 \mathrm{GAE} \mathrm{mg} / \mathrm{gm})$ at 100 $\mathrm{mg} / \mathrm{ml}$ concentration (Fig. 7). Total flavonoid content was maximum in the reflux methanolic extract $(78.56 \pm 0.33$ GAE $\mathrm{mg} / \mathrm{gm})$ followed by ethyl acetate $(65.7 \pm 0.33 \mathrm{QE}$ $\mathrm{mg} / \mathrm{gm})$ and hexane $(63.08 \pm 0.24 \mathrm{GAE} \mathrm{mg} / \mathrm{gm})$ at 100 $\mathrm{mg} / \mathrm{ml}$ concentration (Fig. 8). Steroid content was maximum in the refluxed methanolic fruit extract $(80.38 \pm$ 0.03 sito sterol equivalence $\mathrm{mg} / \mathrm{gm}$ ) followed by hexane (78.74 \pm 0.91 sito sterol equivalence $\mathrm{mg} / \mathrm{gm}$ ) and ethyl acetate $(57.96 \pm 0.10$ sito sterol equivalence $\mathrm{mg} / \mathrm{gm})$ at 100 $\mathrm{mg} / \mathrm{ml}$ concentration (Fig. 9).

\section{HPTLC analysis of phenolic compounds}

The mobile phase for phenolics analysis of macerated, soxhlated, reflux extract with hexane, ethylactate and methanol fruit extracts was toluene:acetone:water (20:40:1) and the resolution was at $254 \mathrm{~nm}$ (Figs. 10 and 11). 3D display of HPTLC chromatogram of $M$. cymbalaria fruit extracts was shown (Figs. 12 and 13). The macerated hexane fruit extract showed 3 peaks with their corresponding ascending order of $\mathrm{Rf}$ values $0.05,0.32$, and 0.45 (Table 2; Fig. 14). The macerated ethyl acetate fruit extract exhibited the presence of 4 spots with the $R f$ values in the ascending order of $0.04,0.25,0.38$ and 0.87 (Table 3; Fig. 15). Methanol extraction by maceration method showed the presence of 3 spots with an ascending order of Rf values $0.04,0.38$ and 0.49 (Table 4; Fig. 16).

The maximum peak area in HPTLC chromatogram of macerated hexane fruit extract of $M$. cymbalaria was 44,330.4. Absorption units and lowest peak area $(1,828.8$ $\mathrm{AU}$ ) was observed at Rf 0.42 and 0.32 respectively. The Rf value of 0.03 coincided with the standard quercetin (Table 2). The maximum peak area in HPTLC chromatogram of macerated ethyl acetate fruit extract of $M$. cymbalaria was 30,534.8 AU and lowest peak area (177.7AU) was observed at $\mathrm{Rf} 0.33$ and 0.86 respectively. The $\mathrm{Rf}$ value of 0.17 coincided with the standard quercetin. The $R f$ value of 0.33 coincided with the standard flavonoid (Table 3). The maximum peak area in HPTLC chromatogram of macerated methanolic fruit extract of M. cymbalaria was 8,235.3 AU and lowest peak area (1,387.1 AU) was observed at $\mathrm{Rf} 0.46$ and 0.38 respectively. The $\mathrm{Rf}$ value of 0.38 coincided with the standard coumaric acid. The Rf value of 0.46 was not coincided with the standard (Table 4).

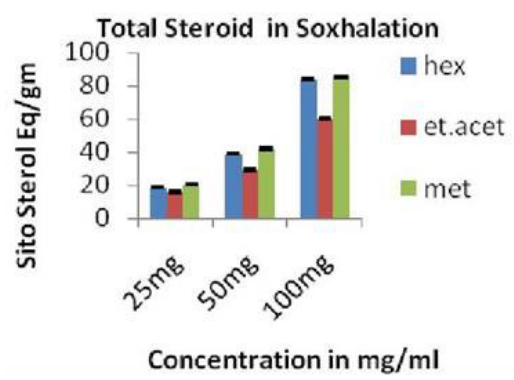

Fig. 6. Total steroid content in soxhlation

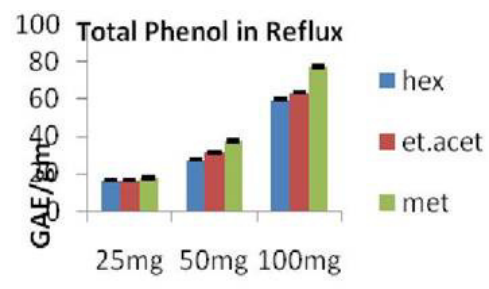

Conccentration in $\mathrm{mg} / \mathrm{ml}$

Fig. 7. Total phenolic content in reflux

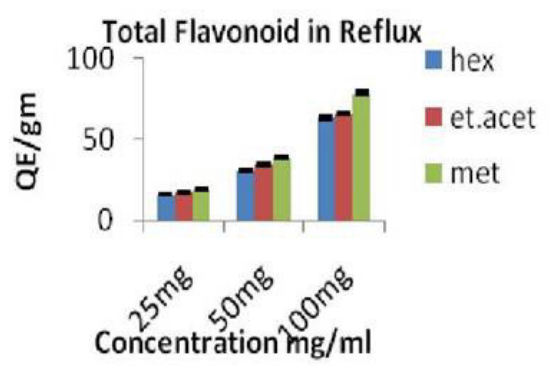

Fig. 8. Total flavonoid content in reflux

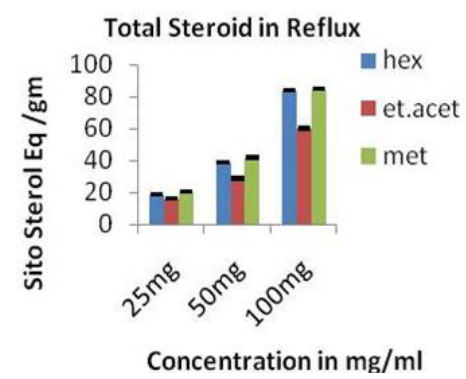

Fig. 9. Total steroid content in reflux

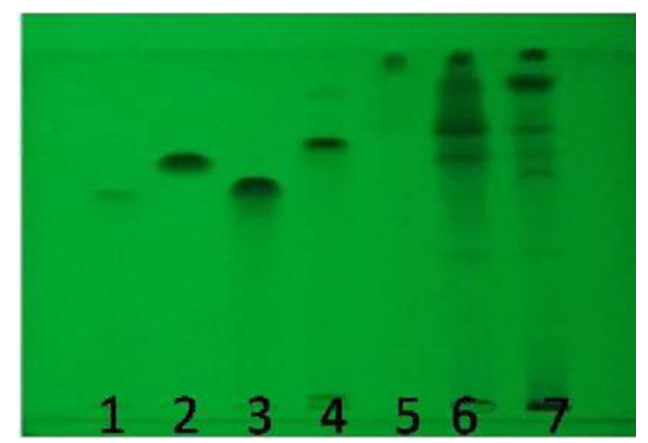

Fig. 10. HPTLC fingerprinting profile for various secondary metabolites present in M. cymbalaria fruit extracts and standards under $254 \mathrm{~nm}$; lane-1- catechin, 2-coumarin, 3- caffeic acid, 4quercitin, 5- hexane, 6ethyl acetate, 7 -methanol (maceration) 


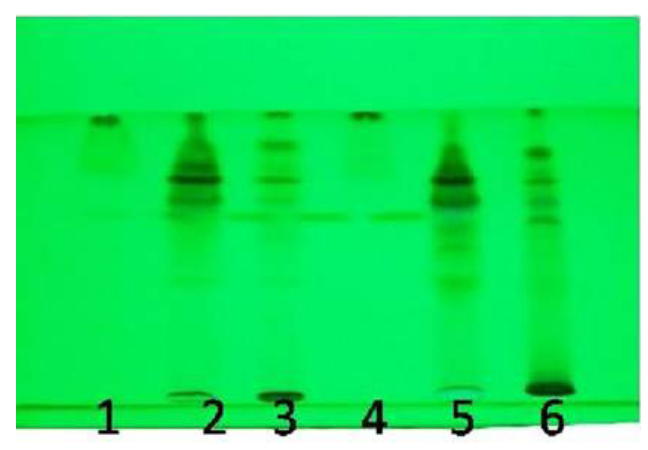

Fig. 11. HPTLC fingerprinting profile for various secondary metabolites present in $M$. cymbalaria fruit extracts and standards under $254 \mathrm{~nm}$; lane-1-hexane, 2- ethyl acetate, 3methanol (soxhalation), lane-4-hexane, lane-5-ethyl acetate, lane-6-methanol (reflux)

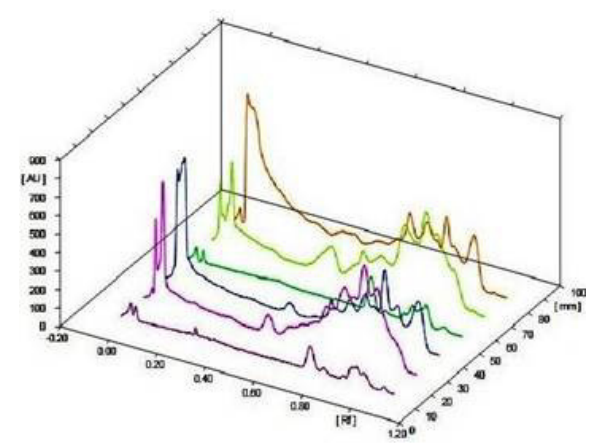

Fig. 13. 3D display of HPTLC chromatogram of $M$. cymbalaria fruit extracts and standards

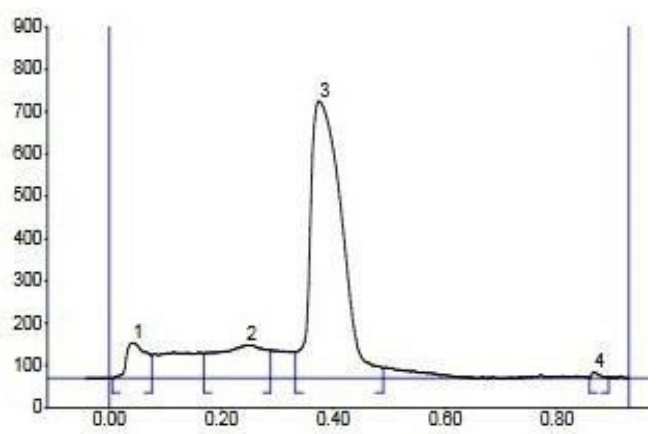

Fig. 15. Maceration fruit extract, HPTLC chromatogram of ethyl acetate fruit extract of $M$. cymbalaria

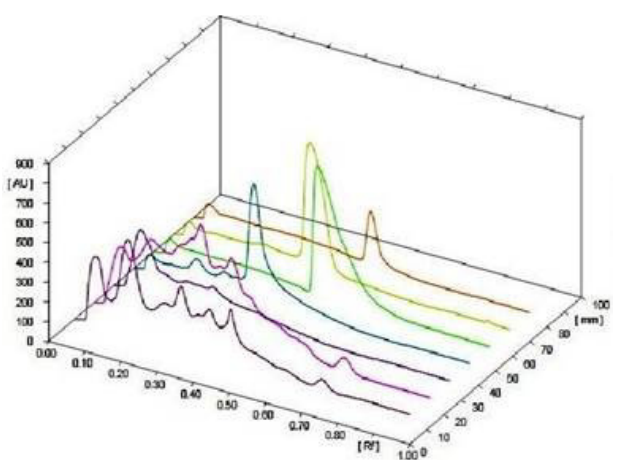

Fig. 12. 3D display of HPTLC chromatogram of $M$. cymbalaria fruit extracts and standards

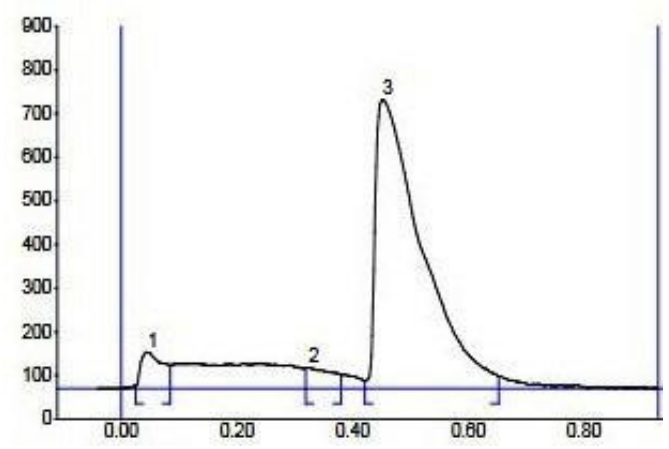

Fig. 14. Maceration fruit extract, HPTLC chromatogram of hexane fruit extract of $M$. cymbalaria

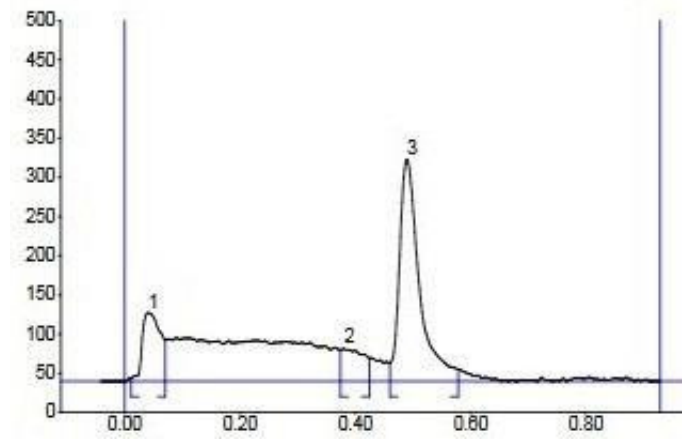

Fig. 16. Maceration fruit extract, HPTLC chromatogram of methanolic fruit extract of M. cymbalaria

Table 2. HPTLC analysis of macerated hexane fruit extract

\begin{tabular}{|c|c|c|c|c|c|c|c|c|c|c|}
\hline \multirow{2}{*}{ Peak } & Start & Start & Max & Max & \multirow{2}{*}{$\operatorname{Max} \%$} & End & End & \multirow{2}{*}{ Area } & \multirow{2}{*}{$\begin{array}{c}\text { Area } \\
\%\end{array}$} & \multirow{2}{*}{$\begin{array}{l}\text { Assigned } \\
\text { substance }\end{array}$} \\
\hline & $\mathrm{Rf}$ & Height & $\mathrm{Rf}$ & Height & & $\mathrm{Rf}$ & Height & & & \\
\hline 1 & 0.03 & 6.4 & 0.05 & 83.9 & 10.55 & 0.08 & 53.9 & $2,663.0$ & 5.45 & quercetin \\
\hline 2 & 0.32 & 46.8 & 0.32 & 48.4 & 6.09 & 0.38 & 32.8 & $1,828.8$ & 3.75 & Unknown \\
\hline 3 & 0.42 & 18.7 & 0.45 & 662.5 & 83.36 & 0.65 & 28.6 & $44,330.4$ & 90.80 & Unknown \\
\hline
\end{tabular}

Table 3. HPTLC analysis of macerated ethyl acetate fruit extract

\begin{tabular}{|c|c|c|c|c|c|c|c|c|c|c|}
\hline \multirow{2}{*}{ Peak } & Start & Start & Max & Max & \multirow{2}{*}{ Max\% } & End & End & \multirow{2}{*}{ Area } & \multirow{2}{*}{$\begin{array}{c}\text { Area } \\
\%\end{array}$} & Assigned \\
\hline & $\mathrm{Rf}$ & Height & $\mathrm{Rf}$ & Height & & $\mathrm{Rf}$ & Height & & & substance \\
\hline 1 & 0.01 & 0.1 & 0.04 & 83.7 & 10.07 & 0.08 & 54.8 & $2,488.7$ & 6.36 & Unknown \\
\hline 2 & 0.17 & 59.6 & 0.25 & 78.2 & 9.40 & 0.29 & 65.5 & $5,902.0$ & 15.09 & quercetin \\
\hline 3 & 0.33 & 62.0 & 0.38 & 654.9 & 78.77 & 0.49 & 24.2 & $30,534.8$ & 78.09 & flavonoid \\
\hline 4 & 0.86 & 1.8 & 0.87 & 14.6 & 1.76 & 0.89 & 2.4 & 177.7 & 0.45 & Unknown \\
\hline
\end{tabular}


Table 4. HPTLC analysis of macerated methanol fruit extract

\begin{tabular}{|c|c|c|c|c|c|c|c|c|c|c|}
\hline \multirow{2}{*}{ Peak } & Start & Start & Max & Max & \multirow{2}{*}{ Max\% } & End & End & \multirow{2}{*}{ Area } & Area & Assigned \\
\hline & $\mathrm{Rf}$ & Height & $\overline{R f}$ & Height & & $\mathrm{Rf}$ & Height & & $\%$ & substance \\
\hline 1 & 0.01 & 4.5 & 0.04 & 87.9 & 21.27 & 0.07 & 52.6 & $2,349.3$ & 19.62 & Unknown \\
\hline 2 & 0.38 & 40.7 & 0.38 & 41.5 & 10.05 & 0.43 & 29.8 & $1,387.1$ & 11.59 & Coumaric acid \\
\hline 3 & 0.46 & 23.3 & 0.49 & 283.6 & 68.68 & 0.58 & 15.4 & $8,235.3$ & 68.79 & Unknown \\
\hline
\end{tabular}

The soxhalated hexane fruit extract showed 10 spots with their corresponding ascending order of RF values $0.01,0.01,0.26,0.34,0.73,0.79,0.87,0.92,0.95$ and 1.04 (Table 5; Fig. 17). The ethyl acetate fruit extract exhibited the presence of 10 spots with the $R f$ values in the ascending order of $0.00,0.03,0.16,0.30,0.47,0.71,0.78,0.82,0.86$ and 0.92 (Table 6; Fig. 18). Methanol extraction by soxhalation method showed the presence of 11 spots with an ascending order of $\mathrm{Rf}$ values $0.03,0.17,0.46,0.57,0.63$, $0.71,0.78,0.81,0.85,0.91$ and 0.99 (Table 7; Fig. 19).

The maximum peak area in HPTLC chromatogram of soxhalated hexane fruit extract of $M$. cymbalaria was 2,674.4 AU and lowest peak area (260.2 AU) was observed at $R f 0.70$ and 0.85 respectively. The $R f$ values of the hexane fruit extract were not matched with any standards (Table 5). The maximum peak area in HPTLC chromatogram of soxhalated ethyl acetate fruit extract of $M$. cymbalaria was 19,554.5 AU and lowest peak area (625.0 AU) was observed at Rf 0.89 and 0.29 respectively. The Rf values of the ethyl acetate fruit extract were not matched with any standards (Table 6). The maximum peak area in HPTLC chromatogram of soxhalated methanol fruit extract of $M$. cymbalaria was (22,747.7 AU) and lowest peak area (406.6 $\mathrm{AU})$ was observed at Rf -0.05 and 0.53 respectively. The Rf value of the methanol fruit extract 0.17 was matched with the standard quercetin (Table 7).

The hexane fruit extract of reflux method evidenced 9 spots with their corresponding ascending order of RF values $-0.02,0.01,0.32,0.70,0.84,0.88,0.93$ and 1.01 (Table 8; Fig. 20). The ethyl acetate fruit extract exhibited the presence of 10 spots with the $\mathrm{Rf}$ values in the ascending order of $-0.01,0.04,0.18,0.45,0.58,0.65,0.75,0.84,0.88$ and 1.03 (Table 9; Fig. 21). Methanol extraction by reflux method showed the presence of 10 spots with an ascending order of $\mathrm{Rf}$ values $-0.02,0.01,0.28,0.40,0.45,0.57,0.68$, $0.75,0.83$ and 0.94 (Table 10; Fig. 22).

The maximum peak area in HPTLC chromatogram of hexane reflux fruit extract of $M$. cymbalaria was 3,797.8 AU and lowest peak area (275.7 AU) was observed at Rf 0.66 and 0.75 respectively. The $\mathrm{Rf}$ value of the hexane fruit extract was not coincided with that of standards (Table 8). The maximum peak area in HPTLC chromatogram of ethyl acetate reflux fruit extract of $M$. cymbalaria was 19,895.7 AU and lowest peak area (220.6 AU) was observed at $\mathrm{Rf} 0.86$ and 1.02 respectively. The $\mathrm{Rf}$ value of the hexane fruit extract was not coincided with that of standards (Table 9). The maximum peak area in HPTLC chromatogram of methanol reflux fruit extract $M$. cymbalaria was 13,969.8 AU and lowest peak area (664.6 $\mathrm{AU}$ ) was observed at Rf 0.59 and 0.05 respectively. The Rf values of methanolic fruit extract was not coincided with that of standards (Table 10).

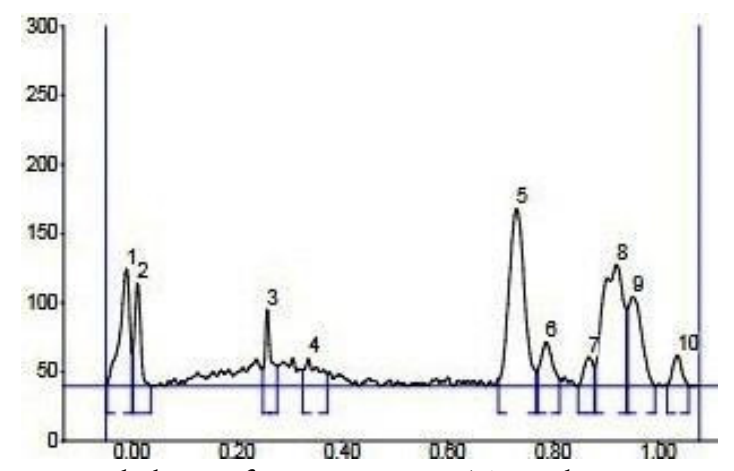

Fig. 17. Soxhalation fruit extract, HPTLC chromatogram of hexane fruit extract of $M$. cymbalaria

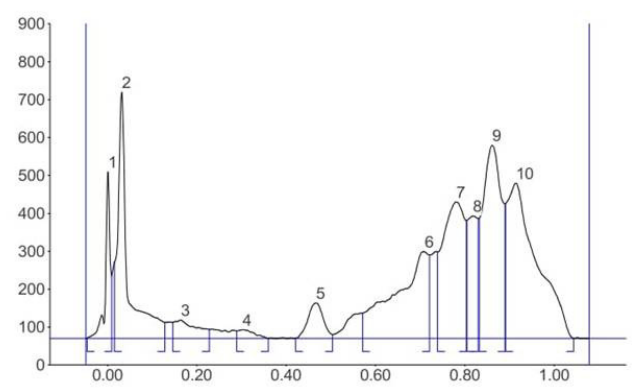

Fig. 18. Soxhalation fruit extract, HPTLC chromatogram of ethyl acetate fruit extract of $M$. cymbalaria

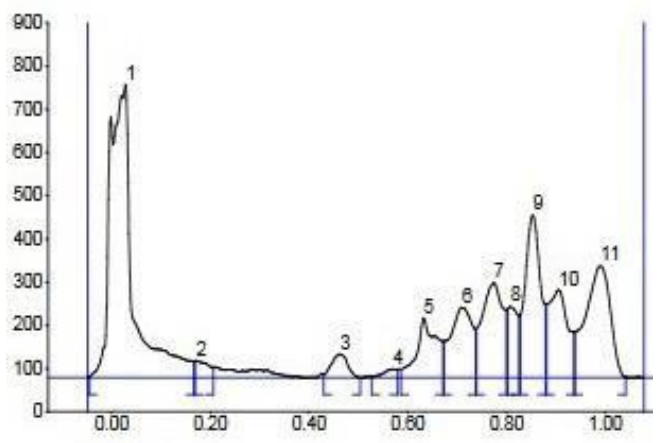

Fig. 19. Soxhalation fruit extract, HPTLC chromatogram of methanolic fruit extract of M. cymbalaria

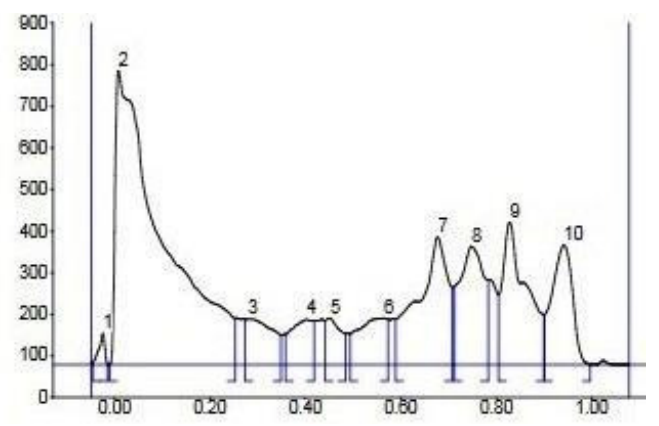

Fig. 20. Reflux - hexane fruit extract 


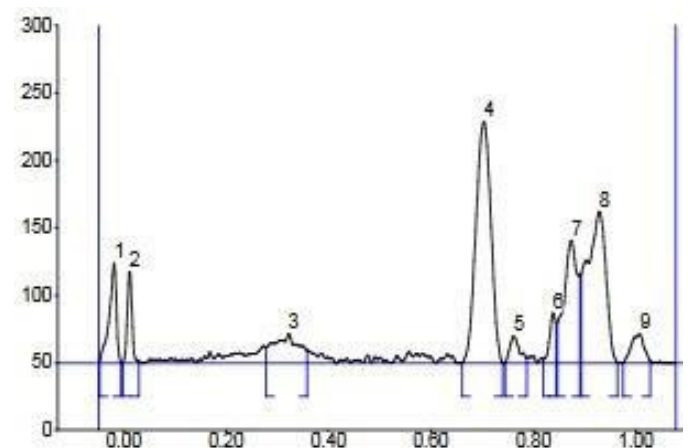

Fig. 21. Reflux - ethyl acetate fruit

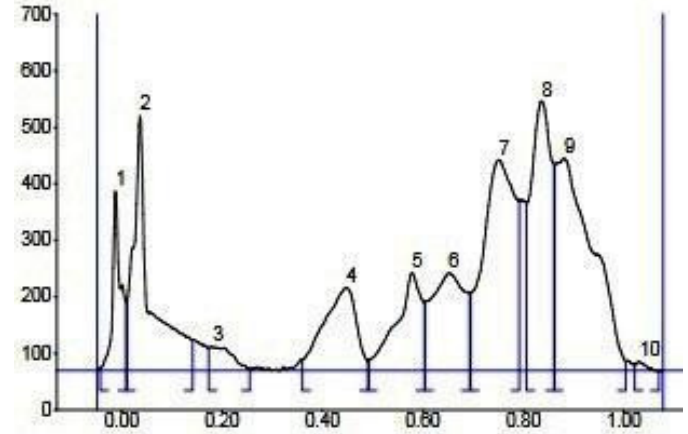

Fig. 22. Reflux - methanol extraction

Table 5. HPTLC analysis of soxhalated hexane fruit extract

\begin{tabular}{|c|c|c|c|c|c|c|c|c|c|c|}
\hline \multirow{2}{*}{ Peak } & \multirow{2}{*}{ Start Rf } & Start & Max & Max & \multirow{2}{*}{ Max\% } & End & End & \multirow{2}{*}{ Area } & \multirow{2}{*}{$\begin{array}{c}\text { Area } \\
\%\end{array}$} & \multirow{2}{*}{$\begin{array}{l}\text { Assigned } \\
\text { substance }\end{array}$} \\
\hline & & Height & $\mathrm{Rf}$ & Height & & $\mathrm{Rf}$ & Height & & & \\
\hline 1 & -0.05 & 1.8 & -0.01 & 84.8 & 14.38 & 0.00 & 23.6 & $1,139.1$ & 11.45 & Unknown \\
\hline 2 & 0.00 & 26.8 & 0.01 & 73.9 & 12.53 & 0.04 & 0.2 & 602.6 & 6.06 & Unknown \\
\hline 3 & 0.25 & 12.5 & 0.26 & 55.4 & 9.39 & 0.28 & 14.7 & 453.3 & 4.56 & Unknown \\
\hline 4 & 0.33 & 12.0 & 0.34 & 19.7 & 3.34 & 0.37 & 9.1 & 379.1 & 3.81 & Unknown \\
\hline 5 & 0.70 & 5.2 & 0.73 & 128.1 & 21.71 & 0.77 & 9.8 & $2,674.4$ & 26.88 & Unknown \\
\hline 6 & 0.77 & 10.5 & 0.79 & 31.7 & 5.38 & 0.81 & 5.0 & 501.7 & 5.04 & Unknown \\
\hline 7 & 0.85 & 0.0 & 0.87 & 21.1 & 3.58 & 0.88 & 13.6 & 260.2 & 2.62 & Unknown \\
\hline 8 & 0.88 & 13.8 & 0.92 & 87.9 & 14.91 & 0.94 & 56.0 & $2,464.4$ & 24.77 & Unknown \\
\hline 9 & 0.94 & 56.2 & 0.95 & 64.7 & 10.97 & 1.00 & 0.00 & $1,207.1$ & 12.13 & Unknown \\
\hline 10 & 1.02 & 1.0 & 1.04 & 22.4 & 3.80 & 1.06 & 0.00 & 267.2 & 2.69 & Unknown \\
\hline
\end{tabular}

Table 6. HPTLC analysis of soxhalated ethyl acetate fruit extract

\begin{tabular}{|c|c|c|c|c|c|c|c|c|c|c|}
\hline \multirow{2}{*}{ Peak } & Start & Start & Max & Max & \multirow{2}{*}{ Max\% } & End & End & \multirow{2}{*}{ Area } & \multirow{2}{*}{$\begin{array}{c}\text { Area } \\
\%\end{array}$} & \multirow{2}{*}{$\begin{array}{l}\text { Assigned } \\
\text { substance }\end{array}$} \\
\hline & $\mathrm{Rf}$ & Height & $\mathrm{Rf}$ & Height & & $\mathrm{Rf}$ & Height & & & \\
\hline 1 & -0.05 & 1.8 & 0.00 & 439.7 & 14.24 & 0.01 & 160.8 & $3,302.2$ & 3.93 & Unknown \\
\hline 2 & 0.02 & 202.6 & 0.03 & 650.0 & 21.05 & 0.13 & 42.3 & $10,299.5$ & 12.27 & Unknown \\
\hline 3 & 0.15 & 42.4 & 0.16 & 49.0 & 1.59 & 0.23 & 23.8 & $1,808.7$ & 2.15 & Unknown \\
\hline 4 & 0.29 & 19.7 & 0.30 & 23.5 & 0.76 & 0.36 & 0.6 & 625.0 & 0.74 & Unknown \\
\hline 5 & 0.42 & 1.9 & 0.47 & 93.6 & 3.03 & 0.50 & 10.8 & $2,346.2$ & 2.80 & Unknown \\
\hline 6 & 0.57 & 66.3 & 0.71 & 229.1 & 7.42 & 0.72 & 220.8 & $12,356.4$ & 14.72 & Unknown \\
\hline 7 & 0.74 & 228.4 & 0.78 & 360.5 & 11.67 & 0.80 & 311.2 & $12,735.5$ & 15.17 & Unknown \\
\hline 8 & 0.81 & 311.6 & 0.82 & 323.1 & 10.46 & 0.83 & 316.6 & $5,418.1$ & 6.46 & Unknown \\
\hline 9 & 0.83 & 317.6 & 0.86 & 509.8 & 16.51 & 0.89 & 355.4 & $15,484.4$ & 18.45 & Unknown \\
\hline 10 & 0.89 & 356.7 & 0.92 & 410.1 & 13.28 & 1.05 & 0.4 & $19,554.5$ & 23.30 & Unknown \\
\hline
\end{tabular}

Table 7. HPTLC analysis of soxhalated methanol fruit extract

\begin{tabular}{|c|c|c|c|c|c|c|c|c|c|c|}
\hline \multirow{2}{*}{ Peak } & Start & Start & Max & Max & \multirow{2}{*}{ Max\% } & End & End & \multirow{2}{*}{ Area } & \multirow{2}{*}{$\begin{array}{c}\text { Area } \\
\%\end{array}$} & \multirow{2}{*}{$\begin{array}{l}\text { Assigned } \\
\text { substance }\end{array}$} \\
\hline & $\mathrm{Rf}$ & Height & $\mathrm{Rf}$ & Height & & $\mathrm{Rf}$ & Height & & & \\
\hline 1 & -0.05 & 3.0 & 0.03 & 677.8. & 29.26 & 0.17 & 37.0 & $22,747.7$ & 33.8 & Unknown \\
\hline 2 & 0.17 & 37.9 & 0.17 & 40.2 & 1.74 & 0.21 & 24.0 & 782.2 & 1.16 & Quercetin \\
\hline 3 & 0.43 & 7.4 & 0.46 & 54.6 & 2.36 & 0.50 & 0.2 & $1,277.5$ & 1.90 & Unknown \\
\hline 4 & 0.53 & 2.0 & 0.57 & 20.7 & 0.89 & 0.58 & 19.9 & 406.6 & 0.61 & Unknown \\
\hline 5 & 0.59 & 20.8 & 0.63 & 137.8 & 5.95 & 0.67 & 84.2 & $3,919.8$ & 5.84 & Unknown \\
\hline 6 & 0.67 & 84.2 & 0.71 & 162.6 & 7.02 & 0.74 & 112.6 & $5,171.2$ & 7.70 & Unknown \\
\hline 7 & 0.74 & 113.6 & 0.78 & 219.5 & 9.47 & 0.80 & 156.5 & $6,734.8$ & 10.03 & Unknown \\
\hline 8 & 0.80 & 157.4 & 0.81 & 165.0 & 7.12 & 0.83 & 143.7 & $2,498.9$ & 3.72 & Unknown \\
\hline 9 & 0.83 & 4.5 & 0.85 & 376.1 & 16.24 & 0.88 & 170.3 & $8,510.1$ & 12.67 & Unknown \\
\hline 10 & 0.88 & 170.4 & 0.91 & 203.4 & 8.78 & 0.94 & 105.5 & $5,776.8$ & 8.60 & Unknown \\
\hline 11 & 0.94 & 106.0 & 0.99 & 258.5 & 11.16 & 1.04 & 1.1 & $9,321.3$ & 13.88 & Unknown \\
\hline
\end{tabular}


Table 8. HPTLC analysis of hexane reflux fruit extract

\begin{tabular}{|c|c|c|c|c|c|c|c|c|c|c|}
\hline Pea & Start & Start & Max & Max & Max & End & End & \multirow{2}{*}{ Area } & \multirow{2}{*}{$\begin{array}{c}\text { Area } \\
\%\end{array}$} & Assigned \\
\hline $\mathrm{k}$ & $\mathrm{Rf}$ & Height & $\mathrm{Rf}$ & Height & $\%$ & $\mathrm{Rf}$ & Height & & & Substance \\
\hline 1 & -0.05 & 1.8 & -0.02 & 74.1 & 11.86 & -0.00 & 0.7 & 752.2 & 6.53 & Unknown \\
\hline 2 & -0.00 & 0.1 & 0.01 & 67.7 & 10.84 & 0.03 & 1.2 & 454.6 & 3.95 & Unknown \\
\hline 3 & 0.28 & 11.7 & 0.32 & 21.7 & 3.48 & 0.36 & 9.2 & 746.9 & 6.48 & Unknown \\
\hline 4 & 0.66 & 0.1 & 0.70 & 179.1 & 28.66 & 0.74 & 0.1 & $3,797.8$ & 32.97 & Unknown \\
\hline 5 & 0.75 & 0.5 & 0.76 & 20.0 & 3.20 & 0.79 & 3.9 & 275.7 & 2.39 & Unknown \\
\hline 6 & 0.82 & 2.8 & 0.84 & 37.2 & 5.95 & 0.85 & 29.3 & 330.4 & 2.87 & Unknown \\
\hline 7 & 0.85 & 30.0 & 0.88 & 91.0 & 14.57 & 0.89 & 64.7 & $1,801.7$ & 15.64 & Unknown \\
\hline 8 & 0.90 & 65.7 & 0.93 & 112.4 & 17.98 & 0.97 & 0.4 & $2,970.9$ & 25.79 & Unknown \\
\hline 9 & 0.98 & 0.3 & 1.01 & 21.6 & 3.46 & 1.03 & 1.8 & 388.8 & 3.38 & Unknown \\
\hline
\end{tabular}

Table 9. HPTLC analysis of ethyl acetate reflux fruit extract

\begin{tabular}{|c|c|c|c|c|c|c|c|c|c|c|}
\hline \multirow{2}{*}{ Peak } & Start & Start & Max & Max & \multirow{2}{*}{$\operatorname{Max} \%$} & End & End & \multirow{2}{*}{ Area } & \multirow{2}{*}{$\begin{array}{c}\text { Area } \\
\%\end{array}$} & \multirow{2}{*}{$\begin{array}{l}\text { Assigned } \\
\text { substance }\end{array}$} \\
\hline & $\mathrm{Rf}$ & Height & $\mathrm{Rf}$ & Height & & $\mathrm{Rf}$ & Height & & & \\
\hline 1 & -0.04 & 5.2 & -0.01 & 317.4 & 12.48 & 0.01 & 122.0 & $3,716.2$ & 4.20 & Unknown \\
\hline 2 & 0.01 & 124.4 & 0.04 & 450.9 & 17.73 & 0.14 & 54.5 & $10,817.3$ & 12.21 & Unknown \\
\hline 3 & 0.17 & 40.4 & 0.18 & 42.5 & 1.67 & 0.26 & 3.0 & $1,415.6$ & 1.60 & Unknown \\
\hline 4 & 0.36 & 19.8 & 0.45 & 146.8 & 5.77 & 0.49 & 18.1 & $6,812.6$ & 7.69 & Unknown \\
\hline 5 & 0.49 & 18.4 & 0.58 & 172.7 & 6.79 & 0.60 & 121.3 & $6,280.6$ & 7.09 & Unknown \\
\hline 6 & 0.61 & 121.7 & 0.65 & 172.7 & 6.79 & 0.70 & 137.2 & $8,276.9$ & 9.34 & Unknown \\
\hline 7 & 0.70 & 137.4 & 0.75 & 372.6 & 14.65 & 0.79 & 300.9 & $17,185.4$ & 19.40 & Unknown \\
\hline 8 & 0.81 & 296.8 & 0.84 & 476.8 & 18.75 & 0.86 & 365.3 & $13,956.1$ & 15.76 & Unknown \\
\hline 9 & 0.86 & 365.3 & 0.88 & 375.2 & 14.75 & 1.01 & 17.6 & $19,895.7$ & 22.46 & Unknown \\
\hline 10 & 1.02 & 11.1 & 1.03 & 15.2 & 0.61 & 1.07 & 0.0 & 220.6 & 0.25 & Unknown \\
\hline
\end{tabular}

Table 10. HPTLC analysis of methanol reflux fruit extract

\begin{tabular}{|c|c|c|c|c|c|c|c|c|c|c|}
\hline \multirow{2}{*}{ Peak } & Start & Start & Max & Max & \multirow{2}{*}{ Max\% } & End & End & \multirow{2}{*}{ Area } & \multirow{2}{*}{$\begin{array}{c}\text { Area } \\
\%\end{array}$} & \multirow{2}{*}{$\begin{array}{l}\text { Assigned } \\
\text { substance }\end{array}$} \\
\hline & $\mathrm{Rf}$ & Height & Rf & Height & & $\mathrm{Rf}$ & Height & & & \\
\hline 1 & 0.05 & 5.7 & 0.02 & 75.0 & 3.07 & -0.01 & 1.6 & 664.6 & 0.59 & Unknown \\
\hline 2 & -0.01 & 0.6 & 0.01 & 706.0 & 28.87 & 0.25 & 111.2 & $49,443.3$ & 44.23 & Unknown \\
\hline 3 & 0.27 & 108.2 & 0.28 & 109.7 & 4.48 & 0.35 & 71.5 & $4,559.4$ & 9.08 & Unknown \\
\hline 4 & 0.36 & 73.3 & 0.40 & 109.0 & 4.46 & 0.42 & 105.5 & $3,655.4$ & 3.27 & Unknown \\
\hline 5 & 0.44 & 104.7 & 0.45 & 111.8 & 4.57 & 0.49 & 74.3 & $2,651.1$ & 2.37 & Unknown \\
\hline 6 & 0.50 & 73.8 & 0.57 & 112.5 & 4.60 & 0.57 & 109.5 & $4,909.3$ & 4.39 & Unknown \\
\hline 7 & 0.59 & 109.8 & 0.68 & 307.3 & 12.57 & 0.71 & 185.5 & $13,969.8$ & 12.50 & Unknown \\
\hline 8 & 0.71 & 189.1 & 0.75 & 284.2 & 11.62 & 0.79 & 203.4 & $10,576.6$ & 9.40 & Unknown \\
\hline 9 & 0.81 & 167.5 & 0.83 & 342.4 & 14.00 & 0.90 & 120.3 & $1,2405.6$ & 11.10 & Unknown \\
\hline 10 & 0.90 & 120.8 & 0.94 & 287.5 & 11.76 & 1.00 & 0.3 & $8,941.6$ & 8.00 & Unknown \\
\hline
\end{tabular}

\section{Discussion}

The results obtained with the hexane, ethyl acetate and methanol extracts showed that hexane was more efficient solvent with a yield of $10 \%$ followed by methanol, ethyl acetate with $8 \%$ and $7 \%$ respectively. This result may be due to the high polarity of methanolic solvent which can draw higher variety of plant constituents than the other solvents (Paulsamy and Jeeshna, 2011).

The phytochemical screening of soxhlated methanolic fruit extract showed the presence of major secondary metabolites such as saponins, flavonoids, glycosides, terpenes, quinones, steroids and alkaloids, while tannins were not detected. The presence of these secondary metabolites suggests that the plant might be of medicinal importance. These compounds are biologically active and exhibit diversified activities. Just et al. (1998) reported the inhibitory effect of saponins on inflamed cells and this has supported the usefulness of this plant in managing inflammation. Saponins cause the leakage of proteins and degradation of cell wall enzymes (Zablotowicz et al., 1996). The presence of phenolic compounds (total phenols and flavonoids) provides pharmacological activities like anticancer (Lin et al., 2008), antioxidant (Khacha-ananda et al., 2013), antimicrobial (Hendra et al., 2011), woundhealing (Nayak and Pinto Pereira, 2006) and antiinflammatory activities (Rathee et al., 2009). Alkaloids were detected in the fruit extracts of $M$. cymbalaria. These alkaloids are toxic against the cells of foreign organisms. These activities have been widely studied for their potential use in the elimination and reduction of human cancer (Nobori et al., 1994). Steroids are important source of sex hormones (Santhi et al., 2011) and also possess antibacterial activities (Raquel, 2007). Presence of steroidal compounds 
in several plants was reported by Savithramma et al. (2011). Terpenoids possess analgesic and anti-inflammatory activities (Nand et al., 2012). The presence of above compounds in $M$. cymbalaria showed their effective medicinal properties.

The maximum amount of phenolic content was observed in macerated, soxhlated and reflux methanolic $M$. cymbalaria fruit extracts. Higher amount of phenolic content is important in regulation of plant growth, development and disease resistance. The results were in agreement with the findings of Geetha and Geetha (2014).

The higher amount of flavonoid content was observed in macerated, soxhlated and reflux methanolic $M$. cymbalaria fruit extracts. Earlier reports revealed that plant phenolic compounds including flavonoids are potent antioxidants, with reported antimutageneic and anticarcinogenic effects (Middleton and Kandaswami, 1994). Similar results were reported in lemon grass by Mirghani et al. (2012).

The higher amount of steroid content was observed in soxhlated, macerated and reflux methanolic $M$. cymbalaria fruit extracts. Similar results were reported in plant extract of Taraxacum officinale by Amin mir et al. (2013).

HPTLC fingerprinting proved to be a liner and accurate method for herbal identification and can be used further in authentication and characterization of the medicinally important plant. HPTLC is an invaluable quality assessment tool for the evaluation of botanical materials, and it allows for the analysis of a broad number of compounds both efficiently and cost effectively. High pressure thin layer chromatography (HPTLC) studies have shown that it is more versatile than ordinary TLC methods, as the spots are well resolved. Further work is needed to characterize the chemical constituents and quantitative estimation with marker compounds is necessary for fixing standards to Momordica cymbalaria. To our knowledge, HPTLC profile of fruit extracts of $M$. cymbalaria with various solvents by different methods of extraction was generated for the first time to ascertain the total number of chemical moieties which will help in designing the method of isolation and characterization of bioactive compounds. The solvent system toluene:acetone:water (20:40:1) standardized in the present work for $M$. cymbalaria with various extracts will provide basic information useful for the isolation, purification and characterization of marker chemical compounds.

\section{Conclusions}

The results of the preliminary phytochemical analysis showed that the soxhlated methanolic fruit extract of $M$. cymbalaria showed more secondary metabolites than hexane and ethylacetate. Quantitative phytochemical analysis (phenolics, flavonoids and steroids) of soxhlated methanolic fruit extract showed the maximum phenolics, flavonoids and steroid content. HPTLC chromatogram of soxhlated methanolic fruit extract showed 11 peaks. Based on the results, soxhlated methanolic fruit extract is rich in secondary compounds and exhibits more biological activity than the other extracts. Hence, future study is needed to isolate potential bioactive compounds from the soxhlated methanolic fruit extract of $M$. cymbalaria.

\section{Acknowledgements}

The authors gratefully acknowledge the financial assistance from University Grants Commission, New Delhi under Rajiv Gandhi National Fellowship Scheme.

\section{References}

Agbor AG, Ngogang YJ (2005). Toxicity of herbal preparations. Cameroon Journal of Ethnobotany 1:23-28.

Agbor AG, Oben JE, Ngogang JY (2005a). Haematinic activity of Hibiscus cannabinus. African Journal of Biotechnology 4(8):833-837.

Amin Mir M, SawhneySS, Jassal MMS (2013). Qualitative and quantitative analysis of phytochemicals of Taraxacum officinale. Wudpecker Journal of Pharmacy and Pharmocology 2(1):001-005.

Bruneton J (1993). Plants medicinales: Phytochimie, Pharmacognosie. 2éme ed. New York, Lavoisier.

Fola A (1993). Local medicinal plants and the health of the consumers. A paper delivered at the PSN/CF PCON organization workshop. Clinical Pharmacy and Herbal Medicine 9:28-31.

Geetha TS, Geetha N (2014). Phytochemical screening, quantitative analysis of primary and secondary metabolites of Cymbopogan citratus (DC) Stapf. leaves from Kodaikanal hills, Tamilnadu. International Journal of PharmTech Research 6(2):521-529.

Hendra R, Ahmad S, Sukari A, Shukor MY, Oskoueian E (2011). Flavonoid analyses and antimicrobial activity of various parts of Phaleria macrocarpa (Scheff.) Boerl fruit. International Journal of Molecular Sciences 12:3422-3431.

Ilango K, Maharajan G, Narasimhan S (2012). Preliminary phytochemical screening and antibacterial activity of fruit pulp of Momordica dioica Roxb. (Cucurbitaceae). African Journal of Basic \& Applied Sciences 4(1):12-15.

Ishtiaq S, Ahmad M, Hanif U, Akbar S, Mehjabeen, Kamran SH (2014). Phytochemical and in vitro antioxidant evaluation of different fractions of Amaranthus graecizans subsp. silvestris (Vill.) Brenan. Asian Pacific Journal of Tropical Medicine 7(1):S342-S347.

Javanmardi J, Stushnoff C, Locke E, Vivanco JM (2003). Antioxidant activity and total phenolic content of Iranian Ocimum accessions. Food Chemistry 83:547-550.

Jeyadevi AR, Sivasudha'T, Rameshkumar A, Sangeetha B, Arul AnanthD, Smilin Bell Aseervatham G (2012). Nutritional constituents and medicinal values of Momordica cymbalaria (Athalakkai) - A review. Asian Pacific Journal of Tropical Biomedicine 2(1):S456-S461.

Just MJ, Recio MC, Giner RM, Cueller MJ, Manez S, Bilia AR, Rios JL (1998). Anti-inflammatory activity of unusual lupine saponins from Bupleurum fruticescens. Planta Medica 64:404407.

Khacha-ananda S, Tragoolpua K, Chantawannakul P, Tragoolpua Y (2013). Antioxidant and anti-cancer cell proliferation activity of propolis extracts from two extraction methods. Asian Pacific Journal of Cancer Prevention 14:6991-6995.

Lin Y, Shi R, Wang X, Shen HM (2008). Luteolin, a flavonoid with potential for cancer prevention and therapy. Current Cancer Drug Targets 8(7):634-646. 
360

Marinova D, Ribarova F, Atanassova M (2005). Total phenolics and total flavonoids in Bulgarian fruits and vegetables. Journal of the University of Chemical Technology and Metallurgy 40(3):255-260.

MerculieffZ, Ramnath S, Sankoli SM, Venkataramegowda S, Murthy GS, Ceballos RM (2014). Phytochemical, antioxidant and antibacterial potential of Elaeagnus kologa (Schlecht.) leaf. Asian Pacific Journal of Tropical Medicine 7(1):S599-S602.

Middleton E, Kandaswami C (1994). The impact of plant flavonoids on mammalian biology: implications for immunity, inflammation and cancer. In: Harborne JB (Ed). The Flavonoids. Chapman \& Hall, London pp 619-652.

Mirghani MES, Liyana Y, Parveen J (2012). Bioactivity analysis of lemon grass (Cymbopogon citratus) essential oil. International Food Research Journal 19(2):569-575.

Nand P, Drabu S, Gupta RK (2012). Phytochemical and antimicrobial screening of medicinal plants for the treatment of acne. Indian Journal of Natural Products and Resources 3(1):28-32.

Nayak BS, Pinto Pereira LM (2006). Catharanthus roseus flower extract has wound-healing activity in S Prague Dawley rats. BMC Complement Alternative Medicine 6(41):1-6.

Nobori T, Miurak K, Wu DJ, Takabayashik LA, Carson DA (1994). Deletion of the cyclin-dependent kinase 4 inhibitor gene in multiple human cancers. Nature 368(6473):753-756.

Obasi NL, Egbuonu ACC, Ukoha PO, Ejikeme PM (2010). Comparative phytochemical and antimicrobial screening of some solvent extracts of Samanea saman pods. African Journal of Pure and Applied Chemistry 4(9):206-212.

Paulsamy S, Jeeshna MV (2011). Preliminary phytochemistry and antimicrobial studies of an endangered medicinal herb Exacum bicolor Roxb. Research Journal of Pharmaceutical, Biological and Chemical Sciences 2(4):447-457.
Raquel FE, Paul BS, Richard ME (2007). Bacterial lipid composition and antimicrobial efficacy of cationic steroid compounds. Biochemica et Biophysica Acta 1768(10):2500-2509.

Rathee P, Chaudhary H, Rathee S, Rathee D, Kumar V, Kohli K (2009). Mechanism of action of flavonoids as anti-inflammatory agents: a review. Inflammation \& Allergy Drug Targets 8(3):229-235.

Roopashree TS, Dang R, Rani SRH, Narendra C (2008). Antibacterial activity of anti-psoriatic herbs: Cassia tora, Momordica charantia and Calendula officinalis. International Journal of Applied Research in Natural Products 1(3):20-28.

Santhi R, Lakshmi G, Priyadharshini AM, Anandaraj L (2011). Phytochemical screening of Nerium oleander leaves and Momordica chrantia leaves. International Research Journal of Pharmacy 2:131-135.

Savithramma N, Linga Rao M, Suhrulatha D (2011). Screening of medicinal plants for secondary metabolites. Middle-East Journal of Scientific Research 8(3):579-584.

Sofowora A (1996). Research on medicinal plants and traditional medicine in Africa. Journal of Alternative and Complementary Medicine 2(3):365-372.

Trease GE, Evans WC (1996). A textbook of pharmacognosy. 14th ed. London: Bailliere Tindall Ltd.

Yamunadevi M, Wesely EG, Johnson M (2011). Phytochemical studies on the terpenoids of medicinally important plant Aerva lanata L. using HPTLC. Asian Pacific Journal of Tropical Biomedicine 1(2):S220S225.

Zablotowicz RM, Hoagland RE, Wagner SC (1996). Effect of saponins on the growth and activity of rhizosphere bacteria. Advances in Experimental Medicine and Biology 405:83-95. 